\title{
Evaluation of HIV1 GP 120-CD4 Binding Inhibition Potentials of the Stem Bark Extracts of Diospyros mespiliformis
}

\author{
${ }^{1 *}$ Mohammed, B., ${ }^{2}$ Abba, S.A. and ${ }^{3}$ Gali, S
}

Department of Microbiology, Bayero University, Kano, Nigeria.

Correspondence author e-mail bshchemiron@yahoo.com Phone: 07012789177

\begin{abstract}
The study was conducted to evaluate the HIV1 gp120-CD4 binding inhibitory potential of crude aqueous, methanol and petroleum ether extracts of Diospyros mespiliformis. The extracts were obtained by Soxhalet extraction. Phytochemical screening, gp120-CD4 binding inhibitory potential, and sub-acute toxicity tests were carried out using standard techniques. Total of six phyto-constituents were identified in the extracts; flavonoids, alkaloids and balsams in aqueous extract, while flavonoids, alkaloids, tannins, balsams, steroids and cardiac glycosides in methanol extract, and flavonoids, alkaloids in the petroleum ether extract. Mean percentage inhibitions of the extracts of Diospyros mespiliformis against HIV-1 gp120-CD4 binding were recorded at various concentrations of the extracts, with $10 \%$ inhibition was recorded at $125 \mu \mathrm{g} / \mathrm{ml}$ in aqueous extract, $13 \%$ and $18 \%$ inhibitions were recorded at 250 and $125 \mu \mathrm{g} / \mathrm{ml}$ in methanol extract respectively, while $3 \%$ inhibition was found in $125 \mu \mathrm{g} / \mathrm{ml}$ of petroleum ether extract respectively. Physical signs of toxicity; weight changes, hair loss, diarrhea, and weakness of the body of the laboratory animals treated with 250 and $125 \mathrm{mg} / \mathrm{kg}$ were observed. There was no significant difference $(P>0.05)$ in serum Aspartate Amino Transferase (AST) and Alkaline Phosphatase (ALP). There were no signs of Inflammation observed in the tissues of animals treated with all the extracts. It can be concluded that the methanol extracts possessed higher anti gp120-CD4 binding activity and extracts were nontoxic to the animals.
\end{abstract}

\section{INTRODUCTION}

Seven million people have been infected with HIV-1 since the beginning of the epidemic in 1981, and about 32 million are now deceased (WHO, 2018). Due to the poor health systems and living conditions, developing countries are the hardest hit by this epidemic. The WHO African region remains most severely affected, with nearly 1 in 25 adults living HIV and accounting for more than two-thirds of the people living with the virus worldwide (WHO, 2018). Sub-Saharan Africa, is where the majority of new HIV-1 infections occur, these countries are home to 25.8 million people infected with HIV-1, accounting for almost $70 \%$ of the global HIV-1 infected population (Ayesha et al., 2016) and there are 1.9 million infected in Nigeria (UNAIDS, 2019).

Despite all the available pharmaceuticals for the treatment of HIV, there is still no cure for the deadly disease and HIV viruses continue to mutate and become resistant to existing drugs. The medical communities throughout the world continue to search for drugs that can prevent HIV infections, treat HIV carriers to prevent them from progressing to full-blown AIDS and treat the AIDS patient. Currently no much has been done on the search for HIV drugs UMYU Journal of Microbiology Research especially from savannah plants that can inhibit the binding of the virus to the susceptible cells (CD4 Lymphocytes), which is an important step in the replication cycle of HIV. The available drugs for the treatment of HIV are expensive and toxic to some extent; hence the need to test some of the Savannah plants for their anti HIV potential.

The Diospyros mispiliformis also known as Monkey Guava or Jackalberry, or West African Ebony is an evergreen tree that reaches up to $20 \mathrm{~m}$ in height, or up to $45 \mathrm{~m}$ in forests. West African Ebony has a wide range of medicinal uses. Different plant parts can be made into variations and used in the treatment of a range of conditions like fever, pneumonia, dysentery, syphilis, leprosy, yaws, menorrhoea, diarrhoea, headaches, arthritis, gingivitis, toothache, cuts and wounds, otitis, stomach pains, sores, ulcers, etc.

The principle constituent appears to be plumbagin, which has been shown to have antibiotic, antihaemorrhagic and fungistatic properties. It is found in the root-bark to a concentration of $0.9 \%$ and but a trace in the leaves (Sharma, 2017). Tannin, saponin and a substance probably identical to scopolamine are also present (Sharma, 2017). www.ujmr.umyu.edu.ng 


\section{UJMR, Volume 5 Number 1, June, 2020, pp 60 - $71 \quad$ ISSN: $2616-0668$}

The antiviral activity of the plant has not been fully exploited despite some claims by traditional medicine practitioners that the plant possesses some antiviral activity. Therefore, there is growing need to evaluate Diospyros mespiliformis for its gp120-CD inhibition potential against HIV1.

\section{MATERIALS AND METHODS \\ Collection of Samples}

Fresh stem bark was collected from Diospyros mespiliformis tree in April, 2018 from Karaye LGA, Kano. The plant was re-identified at the Department of Plant Biology, Bayero University, Kano, where a herbarium number "BUKHAN 121 " was assigned to it. The stem bark was airdried for ten days and then ground in to powder and sieved thoroughly using $0.1 \mathrm{~mm}$ mesh. The powder was kept in a non-absorptive container before use.

\section{Extraction of Phytoconstituents}

The Phytoconstituents were extracted using distilled water, pet-ether and methanol (96\%) as solvents by Soxhlet extraction protocols as described by Tariq et al. (2011). Fifteen grammes of the powdered plant material was wrapped in Whatman filter paper and inserted in to thimble of a Soxhlet extractor which was connected using the manufacturers' guidelines, and then $300 \mathrm{ml}$ of the solvent was heated to boiling. The vapour passed through coils of cool water in the extractor, which enable it to condense and then drop on the plant material. This allows extraction of the soluble components of the plant material. The process is repeated several times until when the soluble components are maximally extracted.

\section{Phytochemicals Analyses}

Some physicochemical characteristics of the extracts were investigated (colour, texture, odour and $\mathrm{pH}$ ) the extracts were also analyzed for the presence of alkaloids, saponins, tannins, steroids, flavonoids, anthraquinones, cardiac glycosides and reducing sugars as described by Adetuyi and Popoola, 2001; Trease and Evans,1989; Sofowora, 1982.

Screening for Anti gp120-CD4 Binding Potential of the Stem Bark Extract using (Human Immunodeficiency Virus type 1 (HIV1) gp120/Glycoprotein 120 ELISA Kit Beijing China)

Three extracts; aqueous, methanol and petroleum ether extracts were used to prepare four (4) different concentrations (1000, 500, 250 , and $125 \mu \mathrm{g} / \mathrm{ml}$ ) respectively in 4 sets of test tubes using dilution buffer and labeled accordingly. The micro plate wells SigmaAldrich, St. Louis, MO, USA were labeled 1-8 vertically representing the four different concentrations in duplicate $(1-2$ for $1000 \mu \mathrm{g} / \mathrm{ml}$, 3-4 for $500 \mu \mathrm{g} / \mathrm{ml}, 5-6$ for $250 \mu \mathrm{g} / \mathrm{ml}$, and $7-8$ for $125 \mu \mathrm{g} / \mathrm{ml}$ ) of the extracts, while the horizontal axis was also labeled A-D for the control and different types of extracts $(A=$ Control, $B=$ Aqueous, $C=$ Methanol, and $D=$ petroleum ether stem bark extracts of Diospyros mespiliformis). Each well was washed three times with wash buffer $(300 \mu \mathrm{L} /$ well) using autowasher. The wells were then aspirated to remove the remaining wash buffer (PBS containing $0.1 \%$ Tripton- X). The plate was inverted and blotted dry with a clean paper towel. One hundred microlitres $(100 \mu \mathrm{L})$ of different concentrations from different extracts were added to the respective wells within 15 minutes without interruption. The plate was covered and incubated at room temperature for 2 hours. The washing and aspiration was then repeated as earlier done. One hundred microlitres $(100 \mu \mathrm{L})$ of detection antibody in working concentration was added to each well. The plate was covered and incubated at room temperature for 1 hour. Then, two hundred microlitres $(200 \mu \mathrm{L})$ of substrate solution (mixture of colour reagent $A$ and $B$ ) were added to each well and incubated for 20 minutes at room temperature and protected from light. After the incubation, $50 \mu \mathrm{L}$ of stop solution was added to each well and the plate was tapped to ensure thorough mixing. The optical density of each well was read after 20 minutes using a micro plate ELISA reader at $450 \mathrm{~nm}$. Percentage gp 120-CD4 inhibition was then calculated below as described by Rege et al. (2010).

Percent inhibition $=\frac{\text { Absorbance of the sample }- \text { Absorbance of the control }}{\text { Absorbance of the control }} \times 100$

Sub-Acute Toxicity Study Using Albino Rats

The rats were sourced from animal room of Department of Biological Science Bayero University, Kano and allowed to acclimatize to the test environment for 7 days during which they were fed with clean water and food. The animals were grouped in to 4 of 4 animals each with the exception of the last group with only 2 animals as negative control to make the total of fourteen (14) rats (weighing 100-106g weight range) for each of the three extracts; aqueous, methanol and petroleum ether extracts of the plant sample. The rats in group I were orally administered $250 \mathrm{mg} / \mathrm{kg}$ (lower) concentrations of aqueous extract and the other two also administered with $500 \mathrm{mg} / \mathrm{kg}$ (higher) concentrations of the aqueous extract. The same procedure was repeated for the group II (methanol extract) and group III (petroleum ether) extracts respectively. 
The remaining two rats were used as negative control by being administered distilled water. During the test, $1.0 \mathrm{ml}$ of each extract concentration was administered orally to each rat and distilled water to each control rat daily for a period of 4 weeks. The rats were then observed for possible physical change(s) on weekly basis for 28 days.

At the end of 28 days, the animals were anaesthesized by dropping each of the animals in a transparent plastic jar saturated with chloroform vapour. The anaesthesized animals were then removed from the jar and blood samples collected through cardiac puncture. Samples were collected in lithium heparin blood bottles, the blood samples were mixed gently, then centrifuged and serum collected for biochemical analyses. While the fresh organs; Liver, Lungs and Kidneys were dissected out of each rat and fixed in $10 \%$ formalin saline for histological investigation.

Biochemical Analyses of the Blood Samples of Swiss Albino Rats.

Biochemical parameters sodium ions, potassium ions alanine aminotransferase, aspartate aminotransferase, alkaline phosphatase, createnine, serum albumin, total proteins, total bilirubins, urea, and bicarbonate ions were determined as described by Cheesbrough (2000).

Histological Examination of Some Organs of Swi Albino Rats

Liver, kidney, and lung tissues of the test albino rats were fixed with $10 \%$ formalin saline, dehydrated with ascending grade of alcohol, cleaned with toluene, and then infiltrated with molten paraffin wax. The microtome section was stained with haematoxylin and eosin staining technique examined with Leica DM 75 microscope and then photographed with Leica ICC 5 HD camera (Auwioro, 2010).

Statistical Analysis

The results were analyzed as mean percentages.

\section{RESULTS}

Physico-chemical Properties and Phytochemical Constituents of Stem Bark Extract of Diospyros mespiliformis

Results showed that the crude aqueous, methanol and petroleum ether extracts appeared dark brown, brown and yellow in colour respectively. All the extracts were gummy in texture and odourless, the $\mathrm{pH}$ ranged from 6.2-7.1 (Table 1).
Six phytochemical constituents including flavonoids, alkaloids, and balsams were present in aqueous extract, while flavonoids, alkaloids, tannins, balsams, steroids and cardiac glycosides were present in methanol extract, only flavonoids and alkaloids were present in petroleum ether extracts (Table 2 ).

gp120-CD4 Binding Inhibition Potentials of Stem Bark Extracts

The Results showed mean percentage inhibition of the extracts of Diospyros mespiliformis against HIV-1 gp120-CD4 binding, where 10\% inhibition was recorded in $125 \mu \mathrm{g} / \mathrm{ml}$ of aqueous extract, whereas, $13 \%$ and $18 \%$ inhibitions were recorded at 250 and $125 \mu \mathrm{g} / \mathrm{ml}$ in methanol extract respectively, while $1 \%$ inhibition was found in $125 \mu \mathrm{g} / \mathrm{ml}$ of petroleum ether extract (Table 3).

Sub Acute Toxicity Study of Stem Bark Extract of Diospyros mespiliformis

There was no hair loss, weight loss, diarrhea or death recorded in the rats after 28 days period of the study (Table 4).

Liver Function Tests

Total protein and A:G ratio were found to be within the normal range in all the extract, but there is a significant increase in albumin and globulin concentration at methanol high concentration extract $(500 \mathrm{mg} / \mathrm{kg})$ (Table 5$)$.

While Table 6, is the liver function test determining Aspartate amino transferase (AST), Alanine amino transferase (ALT) and Alkaline shosphatase (ALP) of the test rats' sera at $500 \mathrm{mg} / \mathrm{kg}$ and $250 \mathrm{mg} / \mathrm{kg}$ of aqueous, methanol, and petroleum ether extract including control respectively. There was a significant increase in AST and ALP in all the extracts both the low and high concentrations. But, ALT concentration values remained within the acceptable range.

Table 7 , is the liver function test in which total and direct bilirubin are determined respectively. There is no any significant increase in both the total and direct bilirubin concentration of the rats' sera.

Kidney Function Test

Table 8, presents the results of kidney function test where serum electrolytes $\left(\mathrm{Na}^{+}, \mathrm{K}^{+}, \mathrm{HCO}_{3}{ }^{-}\right)$ are determined and no significant change seen in all the parameters. All parameters found to be within the normal range (Table 8 ).

Kidney function test results showed that urea level was elevated; however, creatinine concentrations were within the normal range in all the extracts (Table 9). 


\begin{tabular}{llll}
\hline Phytoconstituent & Aqueous extract & Methanol extract & Petroleum ether \\
\hline Flavonoids & + & + & + \\
Alkaloids & + & + & + \\
Saponins & - & - & - \\
Tannins & - & + & - \\
Balsams & + & + & - \\
Glycosides & - & - & - \\
Steroids & - & + & - \\
Cardiac glycoside & - & + & - \\
Phenols & - & - & - \\
Anthocyanins & - & - & - \\
\hline
\end{tabular}

Table 1: Physical Characteristics of the Stem Bark Extract of Diospyros mespiliformis

Histological Observation

Plates 4, present the histopathological observations of the liver, kidney, and lung tissue autopsy of the test rats of the different extracts at various concentrations. There are signs of inflammations seen in the plates of tissues treated with methanol extract, but all the remaining tissues treated with other extracts shown no any sign of inflammation.

Table 2: Phytochemical Constituents of Extracts of Diospyros mespiliformis.

\begin{tabular}{llcll}
\hline Extracts & Colour & Texture & Odour & pH \\
\hline Aqueous extract & Dark brown & Gummy & Odourless & 7.13 \\
Methaol extract & Brown & Gummy & Odourless & 6.31 \\
Pet. ether extract & Yellow & Gummy & Odourless & 6.22
\end{tabular}

KEY: + Positive, - Negative

Table 3: Mean Absorbance and Percentage Inhibition of Extracts of Diospyros mespiliformis Against HIV1 gp120-CD4 Binding at Various Concentrations

\begin{tabular}{|c|c|c|c|c|}
\hline \multirow[b]{2}{*}{ Extracts } & \multicolumn{4}{|c|}{ Concentration $(\mu \mathrm{g} / \mathrm{ml})$} \\
\hline & 1000 & 500 & 250 & 125 \\
\hline Control & $0.146 \pm 0.005(0 \%)$ & $0.146 \pm 0(0 \%)$ & $0.146 \pm 0(0 \%)$ & $0.146 \pm 0.005(0 \%)$ \\
\hline Aqueous & $0.146 \pm 0.005(0 \%)$ & $0.146 \pm 0(0 \%)$ & $0.146 \pm 0.001(0 \%)$ & $0.141 \pm 0.005(10 \%)$ \\
\hline Methanol & $0.146 \pm 0.005(0 \%)$ & $0.146 \pm 0.005(0 \%)$ & $0.128 \pm 0.005(13 \%)$ & $0.120 \pm 0.005(18 \%)$ \\
\hline Petroleum ether & $0.146 \pm 0.005(0 \%)$ & $0.146 \pm 0.005(0 \%)$ & $0.146 \pm 0.005(0 \%)$ & $0.145 \pm 0.005(3 \%)$ \\
\hline
\end{tabular}

Table 4: Sub-Acute Toxicity Effects of Extract of Diospyros mespiliformison Swiss Albino Rat

\begin{tabular}{lllllllll}
\hline Extract & $\begin{array}{l}\text { Conc. } \\
(\mathrm{mg} / \mathrm{kg})\end{array}$ & $\begin{array}{l}\text { Mean } \\
\text { Initial } \\
\text { weight }\end{array}$ & $\begin{array}{l}\text { Mean } \\
\text { final } \\
\text { weight }\end{array}$ & $\begin{array}{l}\text { Mean } \\
\text { weight } \\
\text { difference }\end{array}$ & $\begin{array}{l}\text { \% mean } \\
\text { weight } \\
\text { difference }\end{array}$ & Death & $\begin{array}{l}\text { Hair } \\
\text { loss }\end{array}$ & Diarrhea \\
\hline Control & 250 & 100.5 & 104 & 3.5 & 3.5 & $\mathrm{~N}$ & $\mathrm{~N}$ & $\mathrm{~N}$ \\
& 500 & 101 & 105 & 4.0 & 4.0 & $\mathrm{~N}$ & $\mathrm{~N}$ & $\mathrm{~N}$ \\
Aqueous & 250 & 100.5 & 104.5 & 4.0 & 4.0 & $\mathrm{~N}$ & $\mathrm{~N}$ & $\mathrm{~N}$ \\
& 500 & 101 & 104 & 3.0 & 3.0 & $\mathrm{~N}$ & $\mathrm{~N}$ & $\mathrm{~N}$ \\
\multirow{3}{*}{ Methanol } & 250 & 100.5 & 103 & 2.5 & 2.5 & $\mathrm{~N}$ & $\mathrm{~N}$ & $\mathrm{~N}$ \\
& 500 & 101 & 102.5 & 1.5 & 1.5 & $\mathrm{~N}$ & $\mathrm{~N}$ & $\mathrm{~N}$ \\
& 250 & 102 & 105.5 & 3.5 & 3.4 & $\mathrm{~N}$ & $\mathrm{~N}$ & $\mathrm{~N}$ \\
& 500 & 102.5 & 106 & 3.5 & 3.4 & $\mathrm{~N}$ & $\mathrm{~N}$ & $\mathrm{~N}$ \\
\hline
\end{tabular}

NB: The oral administration time interval was 24hours for 28days period

KEY: $Y=Y e s, N=$ No 
UJMR, Volume 5 Number 1, June, 2020, pp 60 - $71 \quad$ ISSN: $2616-0668$

Table 5: Liver Function Tests for Rats Dosed with Different Extracts at Various Concentrations of Diospyros mespiliformis Stem Bark

\begin{tabular}{lccccc}
\hline Extract & $\begin{array}{c}\text { Dose } \\
(\mathrm{mg} / \mathrm{kg})\end{array}$ & Total Protein & Albumin & \multicolumn{2}{c}{ Concentration of Parameters $(\mathrm{g} / \mathrm{dl})$} \\
\cline { 3 - 6 } & distilled water & 5.884 & 3.824 & 2.00 & A:G Ratio \\
\hline Control & 500 & 6.372 & 4.706 & 2.334 & 1.912 \\
Aqeous HC & 250 & 5.372 & 3.647 & 1.875 & 1.916 \\
Aqeous LC & 500 & 5.093 & 6.118 & 5.025 & 1.218 \\
Methanol HC & 50.697 & 3.176 & 3.479 & 0.912 \\
Methanol LC & 250 & 5.56 & 2.866 & 1.621 \\
Pet. Ether HC & 500 & 5.581 & 4.647 & 2.676 & 1.538 \\
Pet. Ether LC & 250 & 5.442 & 4.118 & &
\end{tabular}

NB: $\quad$ Normal range adopted from Cheesbrough, (2003)

1. Protein $5.2-9.1 \mathrm{~g} / \mathrm{dl}$

2. Albumin $3.5-5.0 \mathrm{~g} / \mathrm{dl}$

3. Globulin $2.0-3.5 \mathrm{~g} / \mathrm{dl}$

KEY:

4. A:G Ratio $0.8-2.0 \mathrm{~g} / \mathrm{dl}$

$\mathrm{HC}=$ High Concentration

$\mathrm{LC}=$ Low concentration

Table 6: Liver Function Tests for Rats Dosed with Different Extracts at Various Concentrations of Diospyros mespiliformis Stem Bark

\begin{tabular}{lcccc}
\hline \multirow{2}{*}{ Extract } & $\begin{array}{c}\text { Dose } \\
\mathrm{mg} / \mathrm{kg}\end{array}$ & & \multicolumn{2}{c}{ Parameters (Concentration in U/l) } \\
\cline { 2 - 5 } & & AST & ALT & ALP \\
\hline Control & 0 & 10 & 6 & 9 \\
Aqeous HC & 500 & 16 & 8 & 10 \\
Aqeous LC & 250 & 16 & 8 & 10 \\
Methanol HC & 500 & 49 & 4 & 37 \\
Methanol LC & 250 & 41 & 8 & 26 \\
Pet. Ether HC & 500 & 47 & 4 & 23 \\
Pet. Ether LC & 250 & 36 &
\end{tabular}

NB:AST Normal values is up to $12 \mathrm{U} / \mathrm{L}$, ALT Normal values is up to $12 \mathrm{U} / \mathrm{L}$ and ALP Normal values is up to 12 $\mathrm{U} / \mathrm{L}$

Normal range source: Cheesbrough (2003)

KEY:

$\mathrm{HC}=$ High Concentration

$\mathrm{LC}=$ Low concentration

Table 7: Kidney Function Tests for Rats Dosed with Different Extracts at Various Concentrations of Diospyros mespiliformis Stem Bark

\begin{tabular}{lcccc}
\hline & Dose & & \multicolumn{2}{c}{ Concentration of Parameters $(\mathrm{mEq} / \mathrm{L})$} \\
\cline { 3 - 5 } Extract & $\mathrm{mg} / \mathrm{kg}$ & $\mathrm{Na}^{+}$ & $\mathrm{K}^{+}$ & $\mathrm{HCO}_{3}^{-}$ \\
\hline Control & 0 & 140.60 & 4.80 & 18.75 \\
Aqeous HC & 500 & 137.00 & 4.67 & 20.83 \\
Aqeous LC & 250 & 137.70 & 3.53 & 20.90 \\
Methanol HC & 500 & 138.45 & 4.67 & 21.05 \\
Methanol LC & 250 & 137.10 & 3.83 & 20.79 \\
Pet. Ether HC & 500 & 141.60 & 4.69 & 21.66 \\
Pet. Ether LC & 250 & 142.65 & 3.55 & 21.86 \\
\hline
\end{tabular}

NB:Normal range source: Cheesbrough (2003)

$\mathrm{K}=3.4-5.3 \mathrm{mEq} / \mathrm{l}, \mathrm{Na}=135-155 \mathrm{mEq} / \mathrm{l}$,

$\mathrm{HCO}_{3}=20-32 \mathrm{mEq} / \mathrm{l}$

KEY: $H C=$ High Concentration, LC= Low concentration 
Table 8: Effect of Various Concentrations of Extracts of Diospyros mespiliformis on Kidney Urea and Creatinine

\begin{tabular}{lccc}
\hline & Dose & & Concentration of Parameters \\
\cline { 2 - 4 } Extract & $\mathrm{mg} / \mathrm{kg}$ & Urea $(\mathrm{mmol} / \mathrm{l})$ & Creatinine $(\mathrm{mg} / \mathrm{dl})$ \\
\hline Control & 0 & 1.965 & 10.00 \\
Aqeous HC & 500 & 9.390 & 9.529 \\
Aqeous LC & 250 & 9.064 & 7.706 \\
Methanol HC & 500 & 13.761 & 9.647 \\
Methanol LC & 250 & 13.164 & 8.941 \\
Pet. Ether HC & 500 & 8.964 & 9.235 \\
Pet. Ether LC & 250 & 8.666 & 8.765
\end{tabular}

NB: Normal range source: Cheesbrough (2003)

Urea $=1.7-9.1 \mathrm{mmol} / \mathrm{l}$, Creatinineis up to $=20 \mathrm{mg} / \mathrm{dl}$

KEY: $\mathrm{HC}=$ High Concentration, LC= Low concentration

Table 9: Effect of Various Concentrations of Extracts of Diospyros mespiliformis on Kidney Total Bilirubin and Direct Bilirubin

\begin{tabular}{lccc}
\hline & Dose & & Concentration of parameters (mg/dl) \\
\cline { 3 - 4 } Extract & $\mathrm{mg} / \mathrm{kg}$ & Total bilirubin & Direct bilirubin \\
\hline Control & 0 & 0.116 & 1.040 \\
Aqeous HC & 500 & 0.256 & 1.109 \\
Aqeous LC & 250 & 0.226 & 1.064 \\
Methanolic HC & 500 & 0.210 & 1.086 \\
Methanolic LC & 250 & 0.198 & 1.038 \\
Pet. Ether HC & 500 & 0.230 & 0.998 \\
Pet. Ether LC & 250 & 0.207 & 0.924
\end{tabular}

NB: $\quad$ Normal range source: Cheesbrough (2003)

Total bilirubin is up to $=0.25 \mathrm{mg} / \mathrm{dl}$, Direct bilirubin is up to $=1.10 \mathrm{mg} / \mathrm{dl}$

$\mathrm{KEY}: \mathrm{HC}=$ High Concentration, $\mathrm{LC}=$ Low concentration
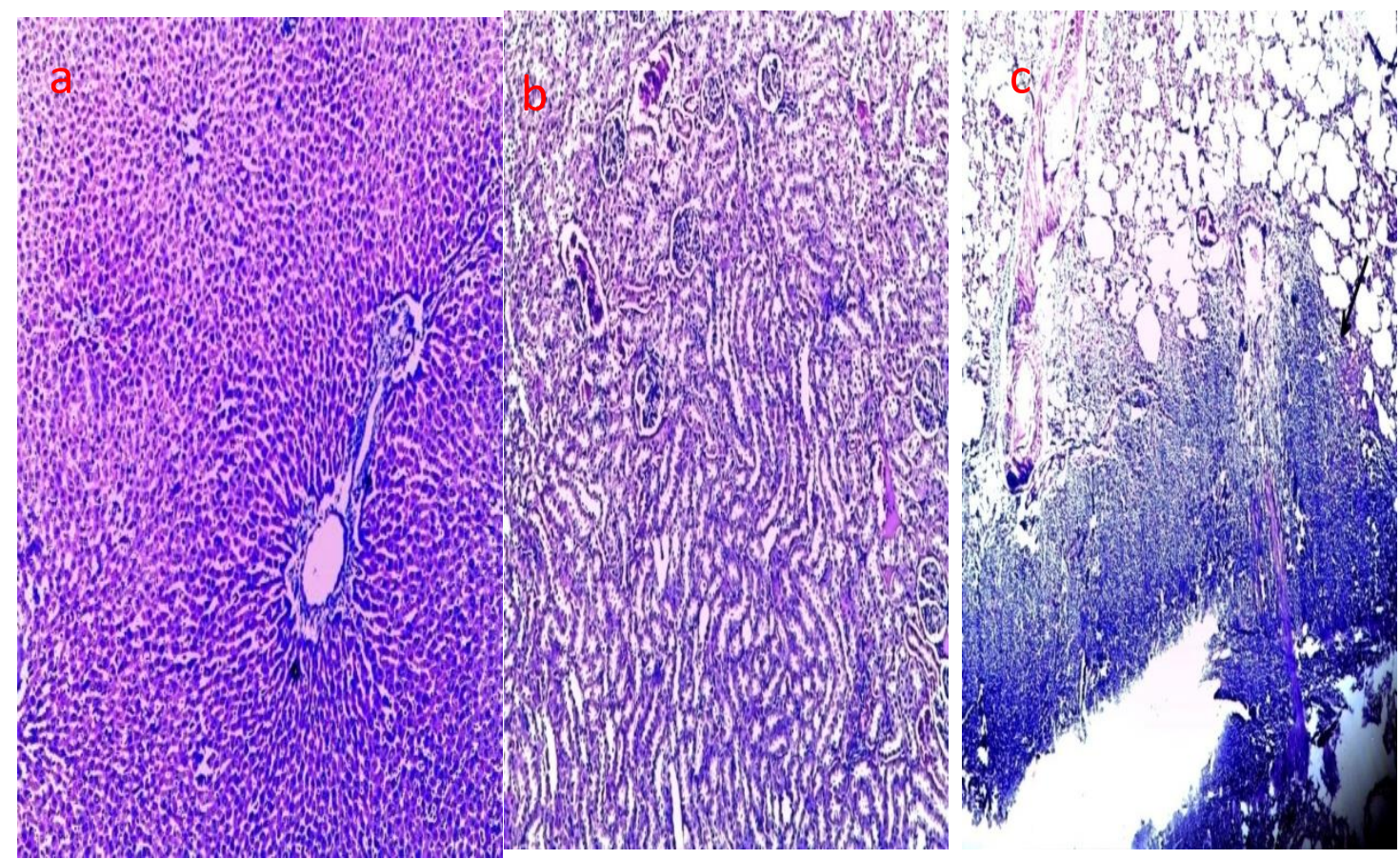

Plate I: Histological images of control tissues of rats treated with Distilled water extract of Diospyros mespiliformis (a. Liver b. Kidney c. Lungs 


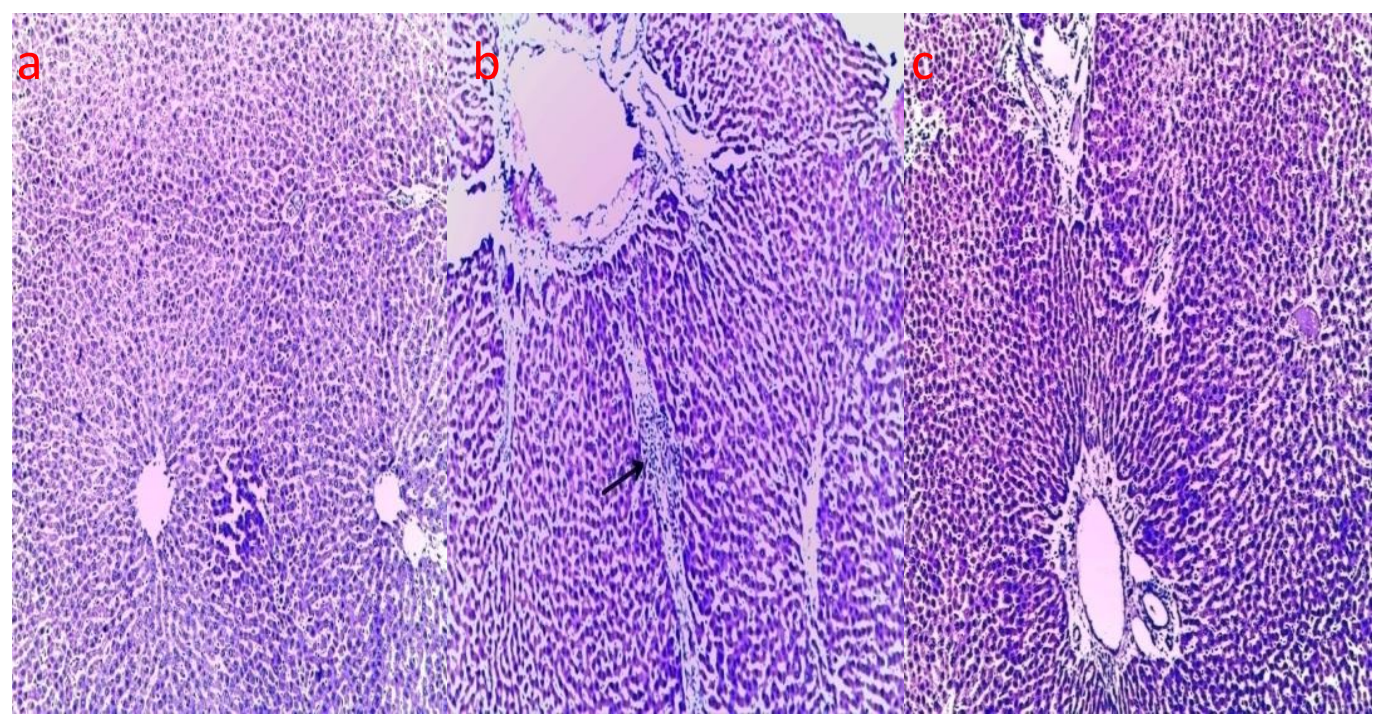

Plate II: Histological images of Liver Tissues of rats treated with different extract of Diospyrosmespiliformis (a. Aqueous extract b. Methanol extract c. Petroleum Ether extract)
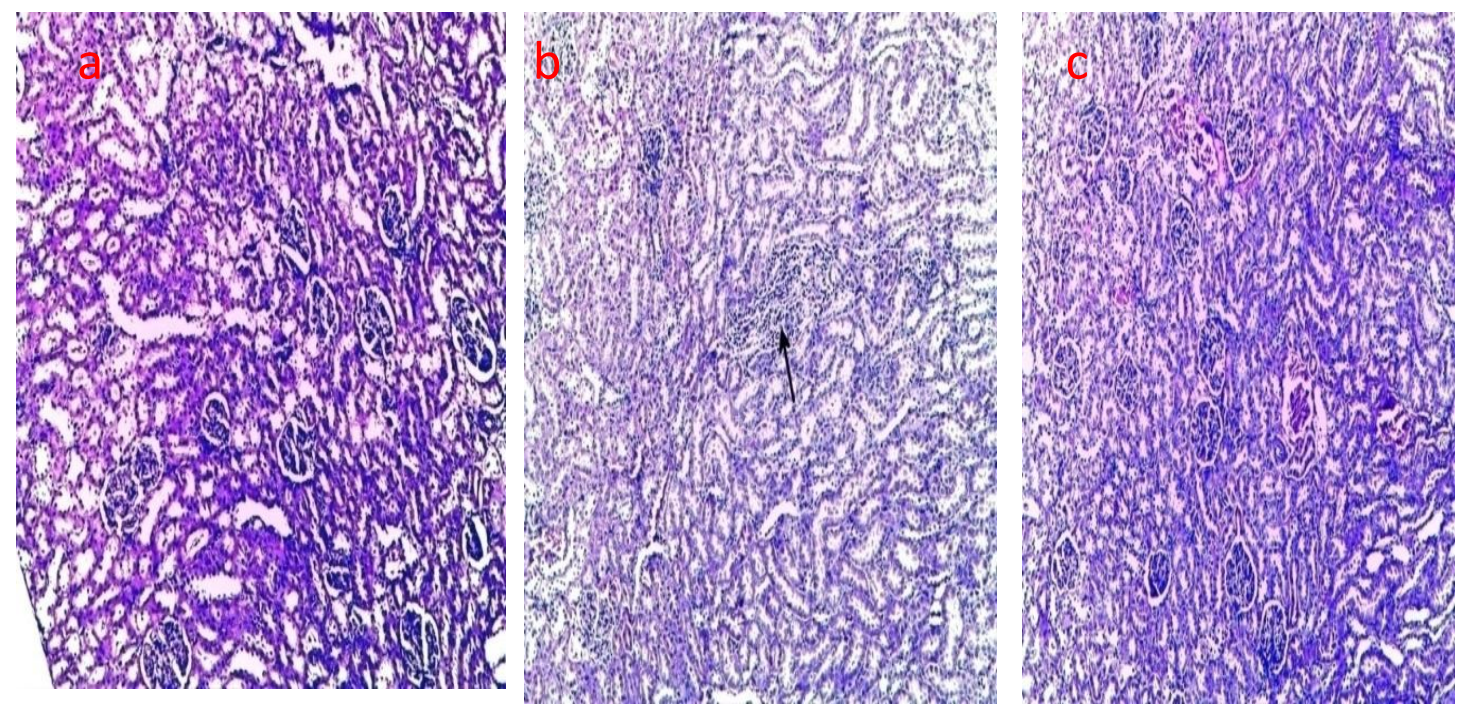

Plate III: Histological images of Kidney Tissues of rats treated with different extract of Diospyrosmesipiliformis (a. Aqueous extract b. Methanol extract c. Petroleum Ether extract)
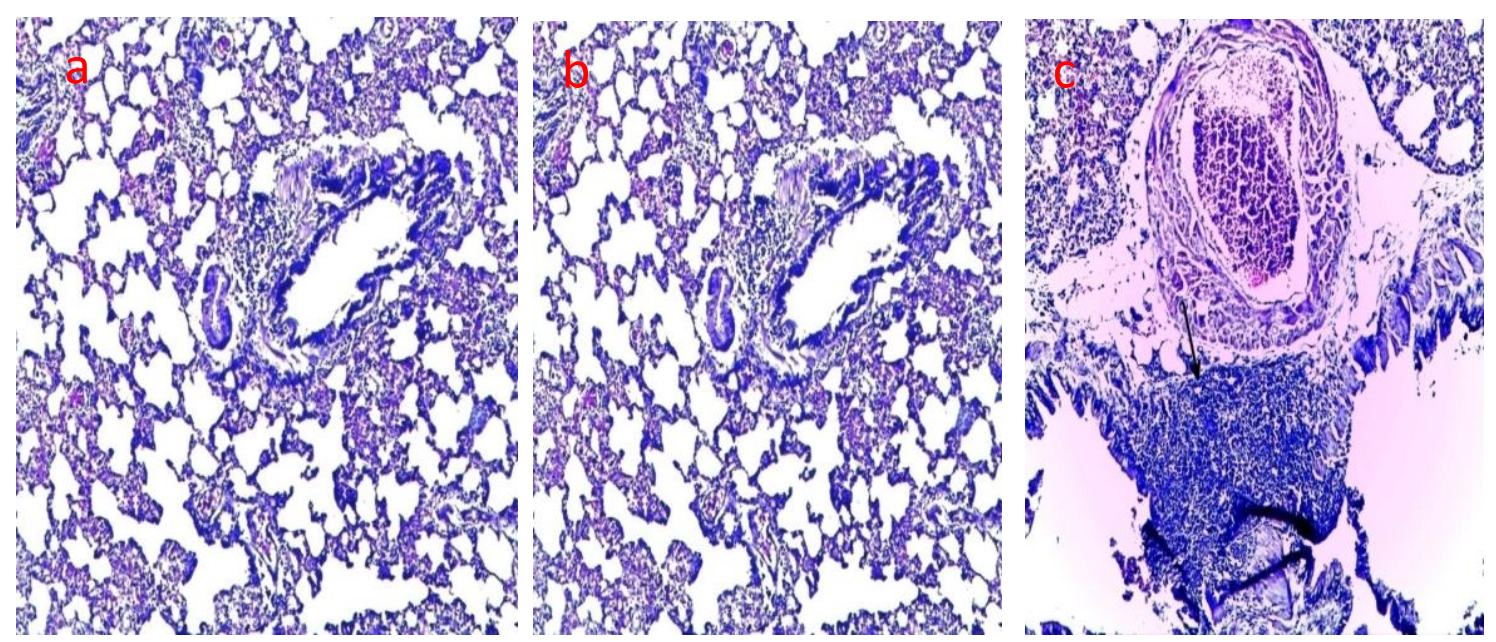

Plate IV: Histological images of Lungs Tissues of rats treated with different extract of Diospyros mespiliformis (a. Aqueous extract b. Methanol extract c. Petroleum Ether extract) 


\section{DISCUSSION}

Results of phytochemical screening revealed six phytochemical constituents (flavonoids, alkaloids, balsams tannins, steroids and cardiac glycosides). Ebbo et al. (2014) have demonstrated the presence of tannins, steroids, cardiac glycosides, alkaloids and flavonoids in the stem bark extract of the plant. The high extraction property of methanol can be related to its amphiphilic property and high polarity index value (5.1) which makes it an ideal solvent for the extraction of polar and nonpolar compounds.

Mahmood et al. (1997) reported the anti gp120CD4 binding activity of flavonoids extracted from Cuscuta reflexa. Similarly, Williamson et al. (2006) highlighted the anti gp120-CD4 binding potentials of flavonoid, epigallocatechingallate (EGCG), extracted from green tea. In addition, Ashok et al. (1995) reported the anti gp120-CD4 binding activity of novel alkaloids extracted from sponge Batzella sp. Gen-ichiro et al. (2004) also reported that tannins possessed inhibition property against HIV-1 gp120-CD4 cell binding. Furthermore, Bridgette et al. (2016) reported that tannins possess gp120-CD4 binding inhibition property. Similarly, Gen-ichiro et al. (2004) reported that all tannins appear to inhibit virus-cell interactions. Thus, in spite of their anti-RT activity, the mechanism by which tannins inhibit HIV may not be associated with this enzyme. The anti gp120-CD4 binding property exhibited by the extracts were higher at lower concentrations, this is one of the important qualities required by an ideal antimicrobial agent. Furthermore, Rege et al. (2010) reported the anti GP120-CD4 binding potential of medicinal plants namely; Ocimum sanctum, Withania somnifera, Tinospora cordifolia, Avicenia, and Rhizophora mucronata, and most of the plants tested exert their anti HIV activity via multiple mechanisms of action, viz. interference with the gp120/CD4 interaction and inhibition of viral RT. Hashim et al. (2015), have elucidated the anti HIV-1 gp120-CD4 binding activity of Leptademia hastate and Vernoniaamygdalina. Moreover, In Woo Park et al. (2009) had reporte $\mathrm{d}$ that Euphorbiaceae, Trigonostemaxyphophyll oides (TXE) and Dipterocarpaceae, Vaticaastrot richa (VAD) inhibit HIV-1 replication likely by blocking HIV-1 interaction with target cells, i.e., the interaction between gp120 and CD4/CCR5 or gp120 and CD4/CXCR4 and suggested the potential of developing these two extracts to be HIV-1 entry inhibitors.

UMYU Journal of Microbiology Research
Kurt and Dominique (2005), worked on anti-HIV agents targeting the interaction of gp120 with the cellular CD4 receptor, where the cyclotriazadisulfonamide compounds tested for their anti gp120-CD4 binding potential using the similar gp120 capture ELISA Kit but different brand, and this was also found to have inhibitory potential for HIV 1 gp120-CD4 binding.

Results of sub-acute toxicity of the test rats showed no case of death, weight loss, hair loss, diarrhea, or weaknesses from the test rats at the end of the 28 days period. This indicated that the extracts were not toxic to the treated animals.

Histological analysis conducted on the organs (liver, kidney, and lung) of the test rats shows no signs of inflammations in the rats treated with all the extracts.

Biochemical analysis of the test rats' sera showed significant elevation $(p<0.05)$ of serum AST and ALP obtained in mice treated with the extracts. Serum alanine aminotransferase (ALT) and aspartate aminotransferase (AST) are useful indices for identifying inflammation and necrosis of the liver (Tilkian et al., 1979). The activity of AST is located in the microsomal and mitochondrial portions of the liver cells as well as in the skin, skeletal and cardiac muscles, pancrease and kidney. ALT measurements are more liver specific than the AST and its activity is usually greater than AST activity at early or acute hepatocelluar disease (Whitby et al., 1989). AST on the other hand tend to be released more than the ALT in chronic liver diseases such as cirrhosis (Whitby et al., 1989). A normal ALT in the presence of elevated activities of AST and lactate dehydrogenase rules out the hepatic origin of the enzyme. In this study, ALT levels are normal but there was no significant changes $(p<0.05)$ in the AST levels. The observed changes in AST were due to administration of $250-500 \mathrm{mg} \mathrm{kg}{ }^{-1}$ body weight of the extracts to the experimental animals compared to the control group.

The activity of Alkaline phosphatase (ALP) is increased in many clinical states; the most important being bone and liver diseases. Accordingly, serum ALP is a useful diagnostic, screening and follow-up tool of cholestatichepatobiliary lesions and osteoblastic bone diseases (Wolf, 1978). Cholestasis is the main, if not the only liver disease responsible for increased plasma alkaline phosphatase activity. Thus, a normal alkaline phosphatase activity, in www.ujmr.umyu.edu.ng 


\section{UJMR, Volume 5 Number 1, June, 2020, pp 60 - $71 \quad$ ISSN: $2616-0668$}

the presence of abnormal levels of other liver function parameters, may be suggestive of liver pathology other than obstruction (Tilkian et al., 1979). In the current research however, the enzyme activity of the animals on different doses differs significantly $(p<0.01)$. This observation, vis-à-vis other clinical pictures ruled out the possibility of liver obstruction.

The effect of extracts on serum albumin level showed increased albumin and globulin values at $500 \mathrm{mg} / \mathrm{kg}$ methanol extract. Albumin is the most abundant of the plasma proteins with the physiological role of maintenance of osmotic pressure, transportation of both endogenous and exogenous substances and serving as protein reserve. The ability of the liver to synthesize albumin is diminished if the synthetic function of the organ is affected (Whitby et al., 1989). While the serum total protein and globulin are within the normal range as in the current study, the assay of serum total protein alone may not portray the true picture of the metabolic state of the individual. This is because the concentration of the individual proteins, do not rise or fall in parallel with one another (Whitby et al., 1989). Increased plasma total protein concentration may be due to dehydration, and increased plasma immunoglobulin concentration may be due to infection. In the current study the serum protein profiles were not significantly different between the animals on different doses of the extract for the toxicity tests. These results demonstrate the fact that the synthetic function of the liver of the animal exposed to oral sub-chronic doses is not affected. Additionally, there is no sign of infection as neither the globulin levels nor the A:G ratio of the animals treated with the extract doses were significantly $(p>0.05)$ affected.

Results of this study also showed that there were no significant changes in the bilirubin levels of the animals treated with the extract doses of the stem bark extract of Diospyros mespiliformis. Consequently, it may be stated that the excretory function of the liver in the rats is not affected significantly as a result of the administration of the oral extract doses. Bilirubin is a useful index of the excretory function of the liver, in addition to its being a useful tool in the assessment of haemolytic anaemia.
Kidney function is affected by a number of factors, which may ultimately result in its failure. Causes of kidney failure include 68 destruction of the tubules in the kidney by drugs, including phytochemicals. As a result, the two main functions of the kidney: the glomerular filtration and tubular re-absorption and secretion may be affected.

Serum Urea level is above the normal range (1.7-9.1 $\mathrm{mmol} / \mathrm{l})$ while the serum creatinine level is below the normal range $(10-55 \mathrm{mg} / \mathrm{dl})$ in this study.

Increased in the serum urea is an indication of renal failure. Though plasma urea concentration is less reliable than the creatinine as an index of GFR, by virtue of the fact that it diffuses back into the renal tubular cells and its plasma concentration is dependent on the state of the liver function and protein intake and oxidation (Tilkian et al., 1979), estimation of the two complement each other in evaluating this function of the kidney.

One of the commonest causes of hyperuricaemia is gout, in which there are either tophi or acute arthritis (Tilkian et al., 1979). Hyperuricaemia as a result of chronic renal failure can be ascertained by correlating uric acid level with urea and creatinine.

In this study the serum electrolytes levels showed sodium and potassium levels to be within the normal range $(166-250 \mathrm{mEq} / \mathrm{l})$ and (3.4-5.3 $\mathrm{mEq} / \mathrm{l})$ respectively. The levels of electrolytes in the blood are the outcome of fine regulatory mechanism of ionic charges and the osmotic balance. This homeostasis is achieved by an interplay involving the kidney, the lungs and endocrine system (Tilkian et al., 1979). Sodium is the major cation of the extracellular fluid where it regulates acidbase equilibrium and protects the body against excessive fluid loss. Hypernatraemia though rare, may occur in dehydration and steroid hormone administration. Hyponatraemia, on the other hand is more common and may be due to chronic sodium losing nephropathy, loss of gastrointestinal secretion through diarrhoea or vomiting, loss from skin as a result of burns, loss from kidneys through the use of diuretics and metabolic loss through starvation or diabetic ketoacidosis. Potassium is the major intracellular cation with similar role to those of sodium. Hyperkalaemia is usually encountered frequently in renal failure, improper use of 


\section{UJMR, Volume 5 Number 1, June, 2020, pp 60 - $71 \quad$ ISSN: 2616-0668}

$\mathrm{K}^{+}$sparing diuretics, hypoaldosteronism, insulin deficiency associated hyperglycaemia, Addison's disease and massive tissue destruction (Eccles, 1993; Tilkian et al., 1979). Excessive renal loss of potassium is associated with diuresis, renal loss as a result of potassium losing nephropathy or as a result of renal tubular acidosis. Other causes of hypokalaemia include excessive loss without adequate replacement as in chronic diarrhoea, malabsorption syndrome, perspiration and chronic fever, chronic stress, poor dietary habit, Cushing's syndrome, hyperaldosteronism, liver disease with ascites, use of some drugs such as indomethacin, phenylbutazone and steroid hormone (Eccles, 1993; Tilkian et al., 1979; Whitby et al., 1989). Plasma bicarbonate ion concentration is increased in respiratory acidosis and metabolic alkalosis but decreased in respiratory alkalosis and metabolic acidosis ((Eccles, 1993; Tilkian et al., 1979, Whitby et al., 1989; Holmes, 1993).

In this study, the serum electrolytes of the animals treated with sub-chronic doses of the extract were not significantly different $(p>0.05)$. This is an indication that the extract may not have any significant effects on the water, electrolyte and acidbase balance not animals' normal serum levels of electrolytes of animals treated with extract of Momordica balsamina have also been reported (Geidam et al., 2004). Excessive renal loss of potassium is associated with diuresis, renal loss as a result of potassium losing nephropathy or as a result of renal tubular acidosis. Other

REFERENCES

Adeniyi, B.A., Odelola, H. A., and Oso, B. A. (1996) Antimicrobial potentials of Diospyros mespiliformis (Ebenaceae). African Journal of Medical Sciences; 25(3):221-4.

Adetuyi, A. O. and Popoola, A. V. (2001): Preliminary phytochemical screening of Wrightiatinctoria Journal of Science Engineering and Technology., 8 (2):3291-3299.

Ashok, D. Patil, N. Vasant, K., Wilhelmus, C. Kokke, M. F., Bean, A. J., Freyer, C. D., Shing, M., Alemseged,T. D., John, F., Brad, C., Ann, L., Breen, R. P., Hertzberg, R. K., Johnson, J. W. W. and Barbara, C. M. P. (1995). Novel Alkaloids from the Sponge Batzella sp.: Inhibitors of HIV gp120-Human CD4

UMYU Journal of Microbiology Research causes of hypokalaemia include excessive loss without adequate replacement as in chronic diarrhoea, malabsorption syndrome, perspiration and chronic fever, chronic stress, poor dietary habit, Cushing's syndrome, hyperaldosteronism, liver disease with ascites, use of some drugs such as indomethacin, phenylbutazone and steroid hormone (Eccles, 1993; Tilkian et al., 1979; Whitby et al., 1989). Plasma bicarbonate ion concentration is increased in respiratory acidosis and metabolic alkalosis but decreased in respiratory alkalosis and metabolic acidosis ((Eccles, 1993; Tilkian et al., 1979, Whitby et al., 1989; Holmes, 1993).

In this study, the serum electrolytes of the animals treated with sub-chronic doses of the extract were not significantly different $(p>0.05)$. This is an indication that the extract may not have any significant effects on the water, electrolyte and acidbase balance not animals' normal serum levels of electrolytes of animals treated with extract of Momordica balsamina have also been reported (Geidam et al., 2004).

\section{CONCLUSION AND RECOMMENDATION}

Six phytochemical constituents; flavonoids, alkaloids, tannins, cardiac glycosides, balsalms and steroids were detected, with methanol extract tested positive in all. The flavonoids, alkaloids and tannins were found to possess inhibition of gp120-CD4 binding interaction. The extracts were found to be well tolerated by the test animals. It is recommended that further research should be carried on the pure isolates of the extracts.

Binding.Journal of organic chemistry 1995, 60, 1182-1188

Auwioro, O.G. (2010). Histochemistry and tissue pathology principle and techniques $2^{\text {nd }}$ edition.

Avert (2014) "HIV and AIDS in Nigeria" Global information and education on HIV and AIDS

Ayesha B.M. Kharsany and Quarraisha A. Karim (2016) HIV Infection and AIDS in SubSaharan Africa: Current Status, Challenges and Opportunities Open AIDS Journal 10: 34-48.

Bhat R. B. Etejere E. O. and Oladipo V. T. (1990). Ethnobotanical Studies from Central Nigeria Vol. 44, No. 3 (Jul. Sep., 1990), pp. 382-390

Bridgette J.C., Sui-Yuan C., Ekambaranellore P., Rahima Y., Viswaraman M., Wilfried www.ujimr.umyu.edu.ng 
P., Doris W., Christiane M., Eiichi N. K., Pascal C., HuguesLortat-Jacob (2016). A Cinnamon-Derived Procyanidin Compound Displays AntiHIV-1 Activity by Blocking Heparan Sulfate- and Co-Receptor- Binding Sites on gp120 and Reverses $T$ Cell Exhaustion via Impeding Tim-3 and PD-1 Upregulation. Journal.pone.

Ebbo A.A., Mammam, M., Suleiman, M.M., Ahmed, A., and Bello A., (2014).Preliminary Phytochemical Screening of Diospyros Mespiliformis. Anatomy and Physiology: Current research. 4:4

Eccles, R. (1993). Electrolytes, Body Fluids and Acid Base Balance. Edward Arnold, Melbourne Auckland, London, Boston.

Evans, P.D. (1980). Biogenic amines in the insect nervous system. Advances in Insect physiology., London 318: 99-122.

Geidam, M.A., Pakmam , I. and Laminu, H. (2004). Effects of aqueous stem bark extract of Momordicabalsamina linn on serum electrolytes and some haematological parameters in normal and alcohol fed rats. Pak. J. Biol. Sci., 7: 1430-1432.

Gen-ichiro, N., Itsuo, N., N. and Takashi, Y. (2004).Journalof Natural Products 53(3):587-95 Institute of Technology

Harborne, J. B. (1973). Phytochemical methods: $A$ guide to modern techniques of plant analysis. Chapman and Hall Ltd, London.; Pp. 279.

Holmes, O., 1993. Human acid-base physiology: A student text. Chapman and Hall Medical, London, Glasgow, New York, Tokyo.

Idu, M. and Onyibe, H.I. (2007) Medicinal Plants of Edo State, Nigeria Volume: 1 I Issue: 2 | Page No.: 32-41 DOI: 10.3923/rjmp 2007.32.41

In-Woo-Park, C. N., Linden, A., Green, T., Wang,Y. L. , Changchun, C., Xinming S., Biao Y., Guangying, C. and Johnny, J. H. (2009. Inhibition of HIV-1 entry by extracts derived from traditional Chinese medicinal herbal plants. BMC Complement Altern Med. 2009; 9: 29.Published online 2009 Aug 5. doi: 10.1186/1472-6882-9-29

Klos, A, Tenner, A.J., Johswich, K.O., Ager, R.R, Reis, E.S, and Köhl, J., (2009). The role of the anaphylatoxins in health and disease.Molecular immunology (14):2753-66. doi: 10.1016/j.molimm.2009.04.027. Epub 2009 May 28.

Mahmood, N. Piacente, Sonia, Burke, A. Khan, Al. Pizza, Cosimo. (1997) Constituents of CuscutoReflexa are anti-HIV Agents. Antiviral Chemistry and Chemotherapy. 70 Vol. 8

Obouayeba, A. P., Méité, S., Boyvin, L., Yeo, D., Kouakou, T. H., N'Guessan, J. D. (2015). Cardioprotective and antiinflammatory activities of a polyphenols enriched extract of Hibiscus sabdariffa petal extracts in wistar rats. Journal of Pharmacognosy and Phytochemistry, 4(1):57-63.

Rege, A.A, Ramkrishna Y.A, Ranjana, A.D. (2010) "Invitro testing of Anti-HIV activity of some medicinal Plants" Indian Journal of Natural products and resources. Vol. 1(2) June 2010: 193-199

Saidu, Y. Bilbis, L.S. Lawal, M. Isezuo, S.A. Hassan S.W. and Abbas, A.Y. (2007).Acute and Sub-chronic Toxicity Studies of Crude Aqueous Extract of Albizziachevalieri Harms (Leguminosae). Asian Journal of Biochemistry, 2: 224-236.

Salehi-Surmaghi, M.H, Aynehchi, Y., Amin, G.H. and Mahhmoodi, Z. (1992), DARU, 2: 1 11.

Segelman, A.B., N.R. Farnsworth and M.D. Quimby, 1969. False negative saponins test results induced by the presence of tannins. Lloydia, 32: 5258.

Seth, S.D and Sharma, Bhawana(2004).Indian Journal of Medical Research; New Delhi Vol. 120, ISS. 1, : 9-1

Sharma, V. (2017). Brief review on the genus Diospyros: A rich source of naphthoquinones Asian Journal of Advanced Basic Science 5(2): 34-53.

Siddiqui, A.A., and Ali, M. (1997): Practical Pharmaceutical Chemistry. $1^{\text {st }}$ edition.C B S Publishers and Distributors, New Delhi, pp-126-131.

Sofowara, A.(1993): Medicinal plants and Traditional medicine in Africa, Spectrum Book LTD, Ibadan. Nigeria 1993; 289.

Sofowora, A. (1982), Medicinal Plants and Traditional Medicine in West Arica, John Wily and Sons. New York, pp-256.

Tilkian, S.M., Conover, M.B. and Tilkian A.G (1979). Clinical implications of laboratory tests; C.V. mosby company; St louis. Toronto. London; 3-44; 117 132; 154-159. 
Trease, G.E. and Evans, M.D., (1989). A text book of Pharmacognosy.13th Ed. BuillerTrindall and Canssel London. Pp 176-180.

UNAIDS (2019). Expanded Data Collection and Analysis Provides Better Understanding of HIV Epidemic in Nigeria. Unaids.org.

Whitby, L.G., Smith, A.F. and Becket, G.J. (1989). Lecture Notes on Clinical Chemistry; Fourth Edition; Blackwell Scientific Publications; Oxford, London, Edinburgh, Boston, Melbourne.; 38 178.
WHO (2018). Global Health Observatory Data. Summary of the Epidemic

Williamson, M. P., McCormick, T. G., Nance, C. L., Shearer, W. T. (2006) Epigallocatechin gallate, the main polyphenol in green tea, binds to the Tcell receptor, CD4: Potential for HIV-1 therapy. Journal of Clinical immunology. 118(6):1369-74.

Wolf, P.L. (1978). Clinical significance of an increased or decreased serum alkaline phosphatase; Arch Pathology Lab Med; 102: 497 -501. 